\title{
THE EFFECT OF FEMALE COMMISSIONERS AND DIRECTORS ON CORPORATE SOCIAL RESPONSIBILITY WITH PROFITABILITY AS MEDIATION ON BASIC AND CHEMICAL INDUSTRIES DURING 2014-2016
}

\author{
Mustika Santi Dyah*, Isnalita \\ Faculty of Economics and Business, University of Airlangga, Indonesia \\ *E-mail: santidyahmustika@gmail.com \\ ORCID: 0000-0002-8097-9129
}

\begin{abstract}
This study aims to examine the effect of female commissioners and directors on CSR with profitability as a mediating variable in Basic and Chemical Industry. The data used in this study was taken from company data on the basic and chemical industries listed on the Indonesia Stock Exchange in 2014-2016. The sampling method uses purposive sampling so that the number of samples in this study is 30 companies. This study uses a quantitative approach. The data analysis technique used is PLS to test hypotheses. The results show that female commissioners, female directors, and profitability have a positive influence on CSR; female commissioners have a negative influence on profitability; female directors did not have a significant influence on profitability, and profitability was not a mediating variable for the influence of female commissioners and directors on CSR.
\end{abstract}

\section{KEY WORDS}

Female commissioners, female directors, profitability, corporate social responsibility.

One important issue that has emerged lately is gender issues. Gender issues have been the subject of debates about social change and development. Many even discuss protests related to discrimination against women (Narwoko \& Suyanto, 2015).

According to Book (2009), women have leadership qualities that companies are looking for now. They not only encourage individuals who are experts in sales and marketing, but also have financial skills and talent in managing people with endless innovations. They use management and financial intelligence to change companies by developing collegial relationships with employees and clients. Women are leaders of a new paradigm where modifying feminine leadership with classical male traits so that they can increase profit and income.

Galbreath (2011) and Nathania (2014) said that female directors had a significant effect on ROA, but did not have a significant effect on ROE. So, this study uses ROA to measure profitability. An increase in profitability will increase CSR disclosure. This is supported by Mulyadi \& Anwar (2012) who say that profitability affects the disclosure of CSR.

The CSR program itself can be supported by the presence of female leadership, in commissioners and directors. This is expressed in the theory of gender socialization that women can better internalize ethical and communal values through their social roles (Hyun et al., 2016). So, women are more receptive to CSR than men.

Most previous research usually theorized about the impact of increasing CSR from female commissioners originating primarily from the literature on gender differences in moral and communal orientation ((Bear et al., 2010; Ben-Amar et al., 2017; Boulouta, 2013; Isidro \& Sobral, 2015). Different results are shown in the research of Nugraheni \& Permatasari (2016) which states that female commissioners have a negative effect on CSR disclosure.

Bernardi \& Threadgill (2011) said that the composition of female directors has a significant positive effect on CSR disclosure. Different results are shown in the study of Sudana \& Arlindania (2011) which states that female directors have a non-significant negative influence on CSR disclosure. Khan (2010) said that the composition of female directors has a not significant positive influence on disclosure of CSR disclosures. 
This study uses size as a control variable. Size is basically grouping companies into several groups, including large, medium and small companies (Suwito \& Herawaty, 2005). Large companies tend to employ more women at each level (Eagly, 2017). Therefore, this study uses large companies, namely companies listed on the Indonesia Stock Exchange. The company used in this study is a company in the field of basic industry and chemistry.

So the hypotheses that can be revealed through this research are:

$\mathrm{H} 1$ : Female commissioners have a positive effect on profitability.

$\mathrm{H} 2$ : Female directors have a positive effect on profitability.

H3: Profitability has a positive effect on corporate social responsibility.

H4: Female Commissioners have a positive effect on corporate social responsibility.

H5: Female directors have a positive influence on corporate social responsibility.

H6: Commissioners and directors of women have a positive influence on corporate social responsibility which is mediated by profitability.

\section{METHODS OF RESEARCH}

This study uses a quantitative approach that is research that intends to confirm the theory that can explain the influence of independent variables on the dependent variable through testing hypotheses using statistical procedures. The dependent variable used is Corporate Social Responsibility as measured by the Corporate Social Responsibility Index (CSRI). The instrument that will be used in this study refers to BAPEPAM regulation No.VIII.G2 regarding annual reports in Aryanti \& Sisdyani (2016) there are 78 disclosure items in accordance with conditions in Indonesia.

The independent variable used is the proportion of female commissioners and the proportion of female directors. In addition, this study uses mediating variables, namely profitability ratios. Profitability ratio is a financial ratio to measure management's ability to obtain profit. The profitability ratio used is ROA, which is formulated as net income after tax divided by total assets. The control variable used is a size that can describe the size of a company based on total assets (Sujianto, 2001).

The type of data used is in the form of quantitative data taken from financial reports and annual reports from samples of companies in the basic and chemical industries listed on the Indonesia Stock Exchange in 2014-2016. The basic and chemical industry sectors consist of 69 companies. The sampling method used in this study was purposive sampling. The number of samples in this study is 30 companies.

Data collection techniques use the documentation method by collecting information and data through literature studies, exploration of literature, financial reports and annual reports on the Indonesia Stock Exchange. Then analyzed using PLS to test the hypothesis. The method of Baron \& Kenny (1986) is used to test the existence of profitability as a mediating variable.

\section{RESULTS AND DISCUSSION}

Female commissioners have a negative effect on profitability as indicated by a path coefficient of -0.292 with a t-statistic value of 3.478 which is smaller than t-table of 1.990 . This situation shows that an increase in the female commissioners has an effect on decreasing profitability.

Female directors do not significantly influence profitability as indicated by a path coefficient of -0.063 with a t-statistic value of 0.711 which is smaller than t-table of 1.990 . This situation shows that the increase or decrease in the female directors did not have a significant impact on the increase and decrease in profitability.

Profitability has a positive effect on CSR indicated by a path coefficient of 0.446 with a t-statistic value of 6.484 which is greater than t-table of 1.990 . This situation shows that an increase in profitability has an influence on increasing CSR. 
Female commissioners have a positive effect on CSR indicated by a path coefficient of 0.374 with a t-statistic value of 6.040 which is greater than t-table of 1.990 . This situation shows that the increase in the female commissioners has an influence on increasing CSR.

Female directors have a positive effect on CSR indicated by a path coefficient of 0.310 with a t-statistic value of 5.516 which is greater than t-table of 1.990 . This situation shows that an increase in the female directors has an influence on increasing CSR.

Size is a control variable in the study, indicated by a path coefficient of 0.226 with a tstatistic value of 3.621 which is greater than t-table of 1.990 . This condition shows that along with the increase in company size, CSR disclosure has also increased.

The results of the study using the Baron \& Kenny (1986) method show that profitability is not a mediating variable for the influence of female commissioners on CSR and the influence of female directors on CSR.

\section{CONCLUSION AND RECOMMENDATIONS}

The existence of female commissioners has a significant negative effect on the profitability of the company. That is, the more women who become commissioners, the profitability of companies tend to decrease.

The existence of female directors does not have a significant influence on the profitability of the company. This means that the existence of women in the position of directors does not have a significant effect on the profitability of the company.

Profitability has a significant positive effect on CSR disclosure. That is, the more profit the company gets, the better the disclosure of CSR.

The existence of female commissioners has a significant positive effect on the disclosure of corporate CSR. That is, the more women who become commissioners, the disclosure of CSR will increase.

The existence of female directors has a significant positive effect on CSR disclosure. That is, the more women who become directors, the disclosure of CSR will increase.

Profitability is not a mediating variable for the influence of female commissioners and directors on CSR.

Recommendations:

In selecting women commissioners and directors, they should not only be due to elements of kinship, but more attention to aspects of quality and accuracy in the field of work handled. Selection with this kind of system is expected to have a better impact on the profitability of the company.

The period of time span of the study can be made longer. This study only took a period of three years, namely 2014 to 2016 , so future research is expected to take a longer period of time, can be five to seven years or more.

\section{REFERENCES}

1. Aryanti \& Sisdyani. (2016). Profitabilitas Pada Earnings Response Coefficient Dengan Pengungkapan Corporate Social Responsibility Sebagai Variabel Pemoderasi. E-Jurnal Akuntansi, 171-199.

2. Baron \& Kenny. (1986). The moderator-mediator variable distinction in social psychological research: Conceptual, strategic, and statistical considerations. Journal of personality and social psychology, 51(6), 1173.

3. Bear, Rahman \& Post. (2010). The impact of board diversity and gender composition on corporate social responsibility and firm reputation. Journal of Business Ethics, 97(2), 207221.

4. Ben-Amar, Chang \& Mcllkenny. (2017). Board gender diversity and corporate response to sustainability initiatives: evidence from the Carbon Disclosure Project. Journal of Business Ethics, 142(2), 369-383.

5. Bernardi \& Threadgill. (2011). Women directors and corporate social responsibility. EJBO: Electronic Journal of Business Ethics and Organizational Studies. 
6. Book. (2009). Why the best man for the job is a woman: The unique female qualities of leadership: Harper Collins.

7. Boulouta. (2013). Hidden connections: The link between board gender diversity and corporate social performance. Journal of Business Ethics, 113(2), 185-197.

8. Eagly. (2017). 100 Women: Do women on boards increase company profits?, BBC NEWS. Retrieved from http://www.bbc.com/news/41365364

9. Galbreath. (2011). Are there gender-related influences on corporate sustainability? A study of women on boards of directors. Journal of Management \& Organization, 17(1), 17-38.

10. Hyun, Yang, Jung \& Hong. (2016). Women on Boards and Corporate Social Responsibility. Sustainability, 8(4), 300.

11. Isidro \& Sobral. (2015). The effects of women on corporate boards on firm value, financial performance, and ethical and social compliance. Journal of Business Ethics, 132(1), 119.

12. Khan. (2010). The effect of corporate governance elements on corporate social responsibility (CSR) reporting: Empirical evidence from private commercial banks of Bangladesh. International Journal of Law and Management, 52(2), 82-109.

13. Mulyadi \& Anwar. (2012). Influence of corporate governance and profitability to corporate CSR disclosure. International Journal of Arts and Commerce, 1(7), 29-35.

14. Narwoko \& Suyanto. (2015). Sosiologi Teks Pengantar and Terapan (4 ed.). Jakarta: Prenadamedia Group.

15. Nathania. (2014). Pengaruh Komposisi Dewan Perusahaan Terhadap Profitabilitas Perusahaan. Finesta, 2(1), 76-81.

16. Nugraheni \& Permatasari. (2016). Perusahaan syariah and pengungkapan corporate social responsibility: Analisis pengaruh faktor internal and karakteristik perusahaan. Jurnal Akuntansi and Auditing Indonesia, 20(2), 136-146.

17. Sudana \& Arlindania. (2011). Corporate governance and pengungkapan corporate social responsibility pada perusahaan go-public di bursa efek Indonesia. Jurnal Manajemen Teori and Terapan| Journal of Theory and Applied Management, 4(1).

18. Sujianto. (2001). Analisis Variabel-variabel yang mempengaruhi struktur keuangan pada perusahaan Manufaktur yang Go Publik di Bursa Efek Jakarta. Jurnal Ekonomi and Manajemen, 2(2), 125-138.

19. Suwito \& Herawaty. (2005). Analisa Laporan Keuangan (4 ed.). Yogyakarta: Liberty. 